\title{
The Unlimited Performativity of Instruction Art: Space Transformer by Yoko Ono
}

Magdalena Holdar

\begin{abstract}
In 1966 American artist Dick Higgins coined the term intermedia as descriptive of contemporary avant-garde art. Building on a system of medial in-betweenness and artistic overlaps, Higgins aimed to show the interconnections between new artistic practices such as mail art, happenings, and action music. This article attempts to read his theory through an artwork whose concept is contemporary to Higgins's intermedia theory but also-through its use of new media-to our time. Yoko Ono's instruction piece Space Transformer consists of three elements: a material artefact; an instruction on how to use the artefact; and the execution of the instruction by the interpreter. The article follows the itinerary between them, concluding that the piece's intermedia qualities are crucial for its emancipatory aim and outcome.
\end{abstract}

A couple of years ago, a friend of mine gave me a small memento from his recent trip to New York. It was a white card, very inconspicuous, with printed text in black, capital letters (Figure I). From the size it could easily be mistaken for a business card, although the text-and indeed the rather eye-catching size of the print-suggested self-awareness and big dreams that was rather at odds with the subtle format. The text on the card read "SPACE TRANSFORMER"; a simple enough message, but nonetheless possible to interpret in a number of different ways and thereby raising a number of questions.

How to cite this book chapter:

Holdar, Magdalena. "The Unlimited Performativity of Instruction Art: Space Transformer by Yoko Ono." In The Power of the In-Between: Intermediality as a Tool for Aesthetic Analysis and Critical Reflection, edited by Sonya Petersson, Christer Johansson, Magdalena Holdar, and Sara Callahan, 99-I 28. Stockholm: Stockholm University Press, 201 8. DOI: https://doi.org/I0.I6993/ baq.e. License: CC-BY. 


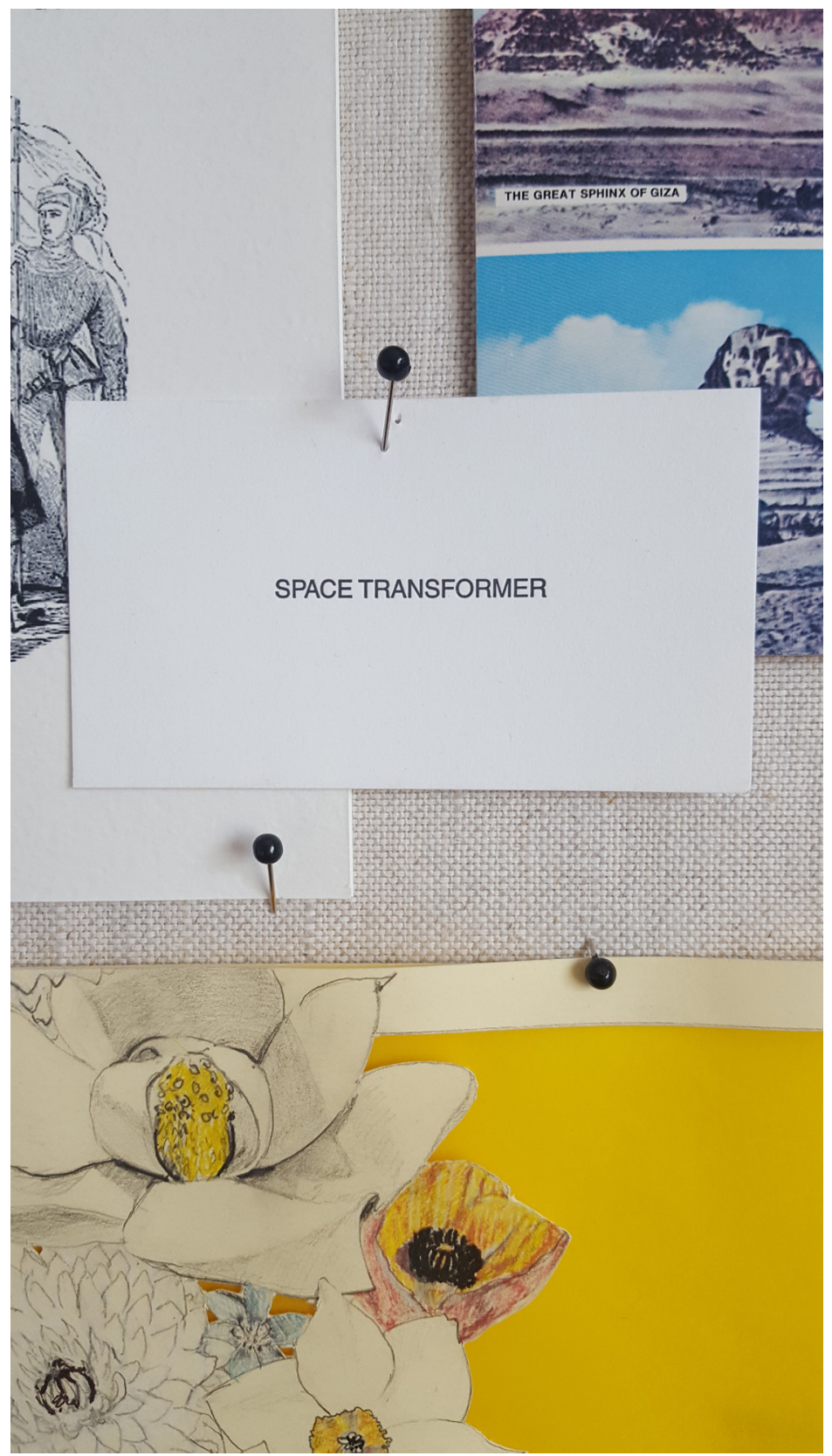

Figure 1. Space Transformer. Yoko Ono, c. 20Iо. Multiple, print on paper, 9×5 cm. Photo: Magdalena Holdar. License: CC-BY-NC-ND. 
As the card's format associated to the identity-producing business card, should I understand the text as the title of its holder? If so, it could associate to a Superhero's trademark: the Space Transformer, whose characteristics find a perfect match in the self-affirming, capital letters-perhaps I could even take advantage of the situation and adopt the title for myself. But maybe it wasn't a title after all? Or rather, maybe Space Transformer was the title of the card itself, empowering this small object with the agency to act on the same level as me, or my friend; that is, making the card-through the printed text-equivalent to a human actant. ${ }^{\mathrm{I}}$ Could this Space Transformer card, eventually pinned to my office notice board, have the power to make a real difference; to "transform space"?

If adding more context around its conception, I actually think it can rightly claim to do so. It had been handed out at a gallery exhibition with works by Yoko Ono, an artist who since the late I950s has developed instructions as an artistic tool to empower her audience, making it active participant rather than passive recipient of the presented work. Its common denominator is not so much medium as the art's dependence on the audience's collective realization of it, according to art historian Kevin Concannon. In his analyses of Ono's works he continuously returns to the artist's wish to empower her audience, and to let it take control of the art. $^{2}$ Nonetheless: before getting to grips with the superpowers of the Space Transformer card, this open-ended piece of paper also needs some theoretical context.

I For a discussion on the agency of things, see Jane Bennett, Vibrant Matter: A Political Ecology of Things (Durham and London: Duke University Press, 20I0) and Gabriel Levine, “The Museum of Everyday Life: Objects and Affects of Glorious Obscurity," Journal of Curatorial Studies, vol. 4, no. 3 (2015): 364-390.

2 Kevin Concannon, "Fluxus and Advertising in the I960s... and Now," Performance Research 7:3 (2002): 59, accessed November I7, 2016, DOI: https://doi.org/IO.IO80/I3528I65.2002.I087I874; Kevin Concannon, "Yoko Ono's Dreams," Performance Research I9:2 (20I4): I03, accessed November I7, 20I6, DOI: https://doi.org/IO.IO80/I3528I65.2002.I087I 874 . 


\section{A 1966 Intermedia Theory}

Despite her background in classical music, Yoko Ono's career from the I950s onwards has come to encompass almost every artistic expression; from performance and drawing to film, composition, poetry, and billboard advertisements. Throughout the years she has moreover been a prominent producer of events, for example, her collaboration with composer La Monte Young in the seminal Chambers Street Loft Series I960-6 I (a number of experimental concerts and performances, whose explicit purpose was "not entertainment" according to the program³), and the administrative and financial support of artist Charlotte Moorman's curatorial work, most notably her annual festival of the avant-garde. ${ }^{4}$ Ono's exploration of media and media transgressions is strongly affiliated to the creative milieu in New York and Tokyo that she took part in from the late I950s, both as artist and producer. On a more general note, Ono's constant movement between and beyond media is in this respect representative for the turn towards performance and technology that we find in North American, European, and Japanese art during this period: the transnational artist network Fluxus, and formations such as Hi Red Center (Tokyo), Experiments in Art and Technology, E.A.T. (New York), and Group Zero (Europe) are but a few examples. It goes without saying that the general modernist art theory and its tendency to stress media separation, objectivity, and detachment to the object of study was too blunt a tool for understanding the new art. However: Ono's artistic activities are like blueprints for the intermedia theory developed by artist Dick Higgins in the mid-I96os, as a means to better catch the specific kind of flux and motion that he saw in the arts at the time. First printed in his publication series Something Else Newsletter (1966), Higgins would make sev-

3 Program for “Terry Jennings" from Chambers Street Loft Series, Yoko Ono's Loft, New York I960. Mimeograph on paper. Accession number 2002.97, Walker Art Center, digitized source material, accessed March 20, 20I 5, http://www.walkerart.org/collections/artworks/program-forterry-jennings-from-chambers-street-loft-series-yoko-onos-loft-newyork.

4 Joan Rothfuss, Topless Cellist: The Improbable Life of Charlotte Moorman (Cambridge: MIT Press, 20I4), 307. 
eral reprints of the essay "Intermedia" over the next decades. The connections between Higgins and Ono are numerous. They knew each other, were part of the same Fluxus circle in New York, and partook in several events together. Nonetheless, they are rarely explicitly connected in the general research on either Ono, Higgins, or Higgins's intermedia theory. ${ }^{5}$

While it is true that theories of art often build on observations, it does not necessarily follow that they are interrelated with the artistic practice per se. In terms of Dick Higgins's intermedia theory, however, I claim that the interconnection between his own context and practice, and the theory he produced, are fundamental for comprehending its essential traits. Thus, Higgins's definition of intermedia was formulated through the artistic practices explored by himself and others in the counterculture movement and anti-institutionalism of the r960s, but he had picked up the term from a lecture by poet Samuel Taylor Coleridge, published as early as I $8 \mathrm{I} 6 .^{6}$ Higgins's "Intermedia" essay was published in I966, but a 200I reprint in Leonardo also includes a commentary by the author (dated I98I) as well as an intermedia chart (dated I995, see Figure 2). ${ }^{7}$

Despite the time span between the publications, comments, chart, and other texts of his, Higgins's definition of intermedia seems to remain consistent. ${ }^{8}$ However, as intermedia was increasingly

5 A recent dissertation by Gregory Laynor, The Making of Intermedia: John Cage to Yoko Ono, I952 to I972 (PhD diss., University of Washington, 20I6) is one of very few research initiatives that more explicitly investigates the publication of Higgins's "Intermedia" article and the artistic practices of its time.

${ }^{6}$ Nicolas Zurbrugg, ed., Art, Performance, Media: 3 I Interviews (Minneapolis and London: University of Minnesota Press, 2004), 20I.

7 Dick Higgins, "Intermedia," Something Else Newsletter I, no. I, (New York: Something Else Press, I966); Dick Higgins, "Intermedia," Leonardo, vol. 34, no. I (200I).

${ }^{8}$ See for example Dick Higgins, Horizons: The Poetics and Theory of the Intermedia (Carbondale: Southern Illinois University Press, I984); Dick Higgins, "Fluxus: Theory and Reception," Fluxus Research, ed. Jean Sellem, vol. 2, no. 2 (I99I); Dick Higgins, Modernism since Postmodernism: Essays on Intermedia (San Diego: San Diego State University Press, I997). 


\section{Intermedia Chart}

\section{Dick Higgins}

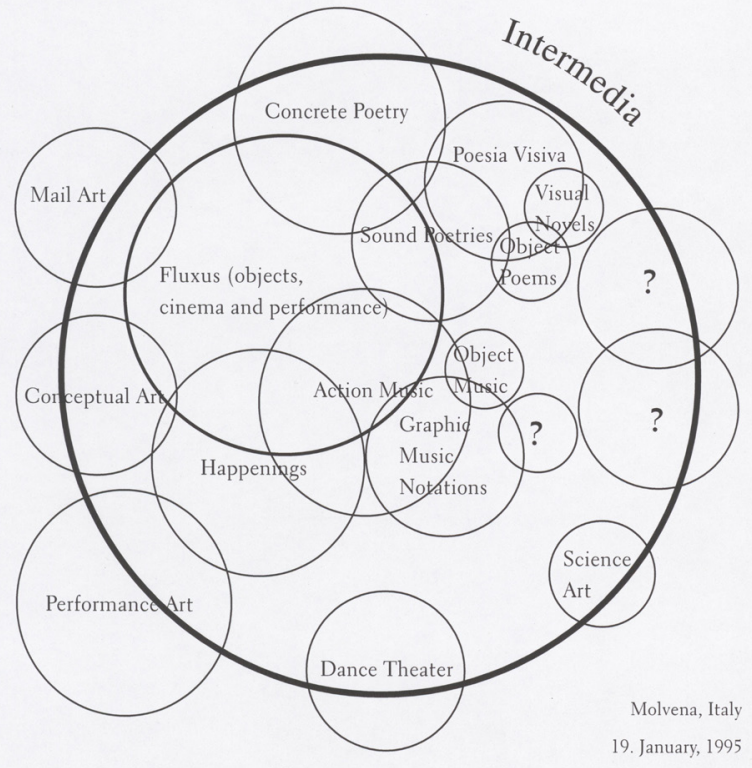

Figure 2. Intermedia chart. Dick Higgins, I995. Photo: Charles Deering, McCormick Library of Special Collections, Northwestern University Libraries. Copyright: Courtesy of the Estate of Dick Higgins. License: CC-BY-NC-ND.

theorized (albeit not necessarily with reference to Higgins's writings), the I98 I comment includes a clear stance towards the new use of the term. After its I 966 publication, Higgins states,

The term [intermedia] shortly acquired a life of its own, as I had hoped. [...] It was picked up; used and misused, often by confusion with the term "mixed media." This last is a venerable term from art criticism, which covers works executed in more than one medium [...]. [By] extension it is also appropriate to such forms as the opera, where the music, the libretto, and the mise-en-scene, are quite separate: at no time is the operagoer in doubt as to whether he is seeing the mise-en-scene, the stage spectacle, hearing the music, etc. Many fine works are being done in mixed media: paintings 
which incorporate poems in their visual fields, for instance. But one knows which is which. ${ }^{9}$

Intermedia, in Higgins's understanding of the concept, was about the fusion of expressions rather than the layering of them. His aim was to open the door to something that could appear confusing and incomprehensible: to establish a vocabulary around art that looked, felt, and sounded like nothing you had experienced before.

In the field of Fluxus research, scholars agree that Dick Higgins was indeed imperative for establishing the term intermedia as theoretical concept in arts and aesthetics. ${ }^{\text {Io }}$ But the lack of references to Higgins in later research, as corroborated by the above quote, also illustrates how the concept soon moved away from the context for which he had found it so productive. Deeply rooted in artistic practice rather than academic research, intermedia was a term with which Higgins hoped to illuminate an aesthetic condition without negotiating art's potential for change. It is clear that his writings have a different agenda from the scholars who have taken the concept further (often without acknowledging his early text). ${ }^{\mathrm{II}}$ Putting more emphasis on theoretical interconnec-

9 Higgins, "Intermedia" (200I): 52.

ro Hannah Higgins, "Intermedial Perception or Fluxing Across the Sensory," Convergence, vol. 8, no. 4 (2002): 59 and Hannah Higgins, Fluxus Experience (Berkeley and Los Angeles: University of California Press, 2002), 9I; Elwell J. Sage, "Intermedia: Forty Years On and Beyond," Afterimage, vol. 33, issue 5 (Mars/April 2006): 25; Jessica Santone, "Archiving Fluxus Performances in Mieko Shiomi's Spatial Poem," Across the Great Divide: Modernism's Intermedialities, from Futurism to Fluxus, eds. Chris Townsend, Alex Trott, and Rhys Davies (Newcastle upon Tyne: Cambridge Scholars Publishing, 2014), I 22; Alison Green, "Intermedia, Exile, and Carolee Schneemann," Across the Great Divide: Modernism's Intermedialities, from Futurism to Fluxus, eds. Chris Townsend, Alex Trott, and Rhys Davies (Newcastle upon Tyne: Cambridge Scholars Publishing, 20I4), I4O.

II The introductory chapter of this publication provides an overview corroborating this conclusion. It is worth mentioning that one theorist who is a recurring reference in intermedia studies, art historian W. J. T. Mitchell, seems to be more affiliated to Higgins's theoretical writings than other scholars in the field. This might possibly be an effect of Mitchell's repeated emphasis on the artwork's agency. It is also a fact that he and 
tions and implications, as customary in many intermedia studies, the concept turns into a tool with which you analyze different materials. To Higgins, on the other hand, intermedia was the effect of the art, rather than an analytical tool. He saw it as the best formulation of what art did, and how we could be assisted in understanding art that escaped conventional definitions. Like the art it stemmed from, the concept itself was in constant flux, morphing as the art morphed and eluding fixed definition. The point is the effect of the mix of artistic expressions, not its separate ingredients. Nonetheless, irrespective of Higgins's absence from later intermedia theory, it is undoubtedly a well-found and catchy concept. And when his specific, artist-based definition of it is removed, it can suddenly be applied on anything from ekphrasis to new media. ${ }^{\mathrm{I2}}$ As this article argues, his theory placed movement and flux (key elements in artistic practice at the time) at stage center in intermedia art, and similar to Ono, he saw the audience as pivotal for identifying intermedia in an artwork.

In his I966 article, Higgins describes intermedia as the fusion of artistic expressions, which can illuminate links and relationships that are found, for example, in creative poetry, object music, happenings, and mail art. Moreover, he says, intermedia in fine arts can be apprehended as "more or less universal [...] since continuity rather than categorization is the hallmark of our new mentality". ${ }^{13} \mathrm{He}$ exemplifies with artist Allan Kaprow's artistic move from painting, to collage, to happening as a form of collage inhabited by people, and composer John Cage's exploration of the intermedia between music and philosophy. Both produced art

Higgins were acquainted and that Mitchell eventually would be the advisor for the PhD project of art historian and Fluxus researcher (and Dick Higgins's daughter) Hannah Higgins. Although this may seem trivial, it is in fact symptomatic that the theorist closest to Higgins's thinking is also uncommonly close to artistic practice.

I2 This conclusion does not disregard the fact that Higgins also expressed great interest in the more technological strata of late I96os thinking. It might be further from his own practice as artist, albeit closer to Ono's, but one can nonetheless note that he for example published several of Marshall McLuhan's theoretical texts through his publishing house, Something Else Press.

I3 Higgins, "Intermedia" (200I): 50. 
that clearly moved away from the media specificity characteristic of modernist theory. Indeed, much of the art that emerged on the post-war art scene were articulations that fused media, which had previously been clearly separated or, at least, whose fusions had not been highlighted in cultural theory before. Despite the tendency to stress activities in the US as key to this creative renegotiation within the arts, it was by no means a singularly Western phenomenon. Artistic intermedia investigations occurred simultaneously but independently of each other in different parts of the world, which makes the period an interesting case of global yet autonomous artistic anarchism.

In the first years of the I960s, Yoko Ono developed the concept of instruction paintings at gallery exhibitions in Tokyo and New York. Instructing the audience to take action in front of a piece like Painting to be stepped on ("Leave a piece of canvas or finished painting on the floor or in the street" ${ }^{14}$ ) or Painting to see the room ("Drill a small, almost invisible, hole in the center of the canvas and see the room through it" ${ }^{{ }^{5}}$ ), the instructions were an act of empowerment and similar to turning the artwork (through the instruction) into a gift to the gallery visitor. She later explained:

Displaying just the instructions as paintings [...] was pushing visual art to its optimum conceptualism; it would open up a whole new horizon for the visual arts. I was totally excited by the idea and its visual possibilities. To make the point that the instructions were not themselves graphic images, I wanted the instructions to be typed. ${ }^{\mathrm{I}}$

With this knowledge regarding Ono's practice in mind, the Space Transformer card would definitely aim to entail real change, both through its own agency and through the action of the interpreter. We often tend to discuss the experimentation within, for example, new music, pop art, experimental dance, and performance throughout

${ }^{14}$ Yoko Ono, Grapefruit: A Book of Instructions + Drawings (New York: Simon and Schuster, 2000 [1964]), unpaginated.

is Yoko Ono, Instruction Paintings (New York and Tokyo: Weatherhill Inc. I995), 29.

I6 Ono, Instruction Paintings, 5 . 
the I960s as strategies to investigate, revise, and reformulate the concept of art. However, it is equally important to recognize the close ties between the counterculture movement's artistic and political veins. ${ }^{17}$ In the transnational network of artists that from I962 collaborated under the name Fluxus (and which included both Yoko Ono and Dick Higgins), life and art were inseparable. Hence, I would claim that both Ono's empowerment of her audience and Higgins's fusion-oriented intermedia theory suggest a more far-reaching aim, beyond the immediate situation that the meeting with art provides. In different ways, they both worked towards demonstrating real change, in the arts (Higgins) and thereby of the world (Ono). They both exemplify countercultural strategies for imposing radical political difference: Yoko Ono, through a card, provides the opportunity to transform space, and Higgins, through theory, enables us to discover the subversive potential in the creative fusion of artistic expressions.

\section{Instructions for Action}

Instruction-based art highlights the route between thing, command, and action. It usually starts off with the material stuff which holds the instruction; a page in a book, a paper nailed to a gallery wall, or a card stuck in your wallet. The material's agency to do something-to perform-suggests that we have a thing rather than a passive object at hand. But the agency of the instruction, irrespective of its material form, is of course dependent on the command itself-what the instruction asks us to do. And there is furthermore a massive difference between receiving an instruction and acting upon it, as a security guard at Seattle Art Museum (SAM) was brutally made aware of when interacting with Yoko Ono's piece Painting to Hammer a Nail in 2009. The instruction reads:

${ }_{17}$ Timothy Scott Brown, "The Sixties in the City: Avant-gardes and the Urban Rebels in New York, London, and West Berlin," Journal of Social History 46:4 (20I3): 8I9, accessed November I7, 20I6, DOI: https://doi. org/IO.I093/jsh/ shtoo7. 
Hammer a nail into a mirror, a piece of glass, a canvas, wood or metal every morning. Also, pick up a hair that came off when you combed in the morning and tie it around the hammered nail. The painting ends when the surface is covered with nail. ${ }^{18}$

But over the course of a couple of weeks in exhibition, visitors did not stop when the board was covered with nails. Instead, they continued attaching a wide array of bits of paper onto the painting and the wall around it, expanding their interpretation of the instruction so that they could participate in the work by prolonging the timeline of the painting, beyond its end "when the surface is covered with nails." Chewing gum wrappings, receipts, and diverse scraps of found material covered the board and wall.

Ono's artistic demands to the museum stated that things were allowed to be added to the artwork (and thereby overruling the traditional practice of "not touching the artwork"), but not taken away from it. The museum security guard (also an artist), however, decided to clear the painting from the extraneous material, arguing that SAM had "allowed the public to obstruct the artwork." I9 She referred to her action of tidying up the artwork as a performance, but that did not hinder the museum from firing her for intervening with the artistic intention of the piece.

In line with her artistic strategy to hand over her instructions into the hands of others, not meddling with the effects they reach, Ono concluded when informed about the controversy:

I thought it [i.e. the painting being covered in scraps of paper] was hilarious, and loved it! Then a woman decided that was not good, and tried to put the work back to its original shape. Then the museum decided that the woman should not have done that and fired her. Things keep happening, very much like life itself, with the original instructions being the genesis of it all. Life is beyond criticism, much less mine. ${ }^{20}$

${ }^{18}$ Ono, Grapefruit, unpaginated.

i9 The cited statement by the security guard/artist is from her blog, here quoted from Rebecca Close, "Yoko Ono Work Controversy," Art Asia Pacific (Nov/Dec 2009): unpaginated, accessed September 22, 2016, http://artasiapacific.com/Magazine/66/YokoOnoWorkControversy.

${ }_{20}$ Ono quoted in Close, "Yoko Ono Work Controversy," unpaginated. 
The incident goes to show that thing, command, and action can travel in unexpected directions. They might be compared to "creative touchdowns," to use a sports term, or "productive resting points" that are performatively bound together through the work. Each point has a body of its own: the physical body of Ono's instruction for Painting to Hammer a Nail, printed and published in many different fora; the performative command as displayed at the museum; the final action of visitors performing the instruction; and that of the security guard, acting on the performance of others. However, they also create a larger, performative body of fusing media, which Dick Higgins would refer to as intermedia.

Higgins and Ono were part of a transnationally spread tendency to expand the formulations of artistic work. Although sometimes disparate in their expressions, the creative activities and cross-references between music, poetry, visual art, etc., which were central for these artists' position next to established institutions and traditional definitions of art, had many similarities in attitude and performative agency. Expressively disassociating his theoretical approach from any wish to organize understanding of the arts through marking differences, Higgins explores the similarities and links between different phenomena in order to uncover a wider picture-to bind the pluralistic world together into a more coherent whole. One could connect this to the influence of other contemporary thinking as well, for example John Dewey's significant writings on art as integrated in life. One could also refer to it as art ecology and thereby pronounce the continuity of thought into present day theory. Indeed, if treating all arts as aspects of the same prism, they would communicate the similar interchange of complex phenomena in life too. Also, stressing the fused layers of media as productive and performative, Higginsthrough theory-illuminates the continuous exchange between artists acting in the different fields, which possibly was an insight that stemmed from his own artistic practice. But Higgins's concentration on productive fusions pays little attention to the conditions within each demarcated practice in his intermedia chart (Figure 2): how letters and words are used in concrete poetry, and how the postal system is manipulated in mail art. Importantly however, intermedia does not necessarily entail the fusion of art 
forms only. As Higgins declares, it can also entail "the conceptual fusion of two or more previously defined areas of art or concern," as was the case with Cage's philosophy cum music referred to earlier. ${ }^{21}$ This surely brings new and almost unlimited possibilities to the fore, which needs a further investigation. What piece would provide a better case for this task than Yoko Ono's Space Transformer, which starts off with an artist's idea and (possibly) ends with global change?

\section{Space Transformer: An Itinerary of Things and Actions}

To the interpreter, Space Transformer begins with card-a material something that can be handed out, given away, or saved for later. But in order to interpret and perform the card's text, one also needs its instruction, which reads: "Attach a card saying SPACE TRANSFORMER to the room and/or object you wish to transform." 22

Bordering on trivial in both form and message, the card and instruction are nonetheless the starting point for an almost limitless performativity. In this sense, the piece makes it perfectly clear that its author Yoko Ono has a background in music. Instructions function similarly to a musical score: they present the foundation for action, but in doing so, they simultaneously leave the piece open for the recipient's interpretation. You receive this initial, material origin for an action-the printed card and its instruction having the same function as sheet music-but you also have the possibility to perform it in many different ways. The details of a traditional musical score might produce a certain frame for individual interpretation, letting variations appear in, for example, tempo and articulation, whereas the variations of performances of instructions can be almost unlimited. Ono's friend and colleague La Monte Young wrote a composition with the instruction "Draw a straight line and follow it" (c. I960/6I). When

${ }_{21}^{21}$ Higgins, Modernism since Postmodernism, 93.

${ }^{22}$ Instruction as published on Yoko Ono's Facebook page in October 20I I, one of several media for publication: accessed October I 8, 20I6, https:// www.facebook.com/yokoonopage/posts/IOI 504 I 7555695535 . 
performing Young's piece in I962, artist and composer Nam June Paik rolled out meters of white paper on the floor, dipped his hair in a bucket containing calligraphy ink and tomato juice, and drew the straight line by pressing his head against the paper and backing down its full length. ${ }^{23}$ The example illustrates the possibility of free interpretation of the suggested action, but it is likewise important to stress the commitment that follows from receiving and acting on these instructions. An instruction can be seen as a gift of sorts as the author/composer/artist passes on the piece to an unknown recipient-a gift to take care of and hopefully treasure. If so handled, the piece can live on through different interpretations and by being repeatedly re-enacted, which grants it a lifetime that might very well exceed that of its author. For many artists in Fluxus, authorship was, however, of less importance, and claiming it could even be considered contradictory to the collectiveness of the network. Space Transformer is not signed, possibly for the same reason. The piece is now in your hands; the identity of the author is (supposedly) no longer relevant.

In fact, in this particular case it seems that you do not even need access to the prefabricated card in order to perform the piece. I received mine from a friend who had picked it up at a gallery exhibition, but the instruction-separated from my card but retrievable via the internet-suggests that any card can do, as long as its text says "Space Transformer." Thus, Ono does not only hand over the performance of the piece to an unknown recipient; she also empowers him or her to produce the actual card that transforms space. Her role as artist and originator turns into that of a creator of concepts, or of thoughts, rather than creator of objects.

Indeed, realizing the status of the printed card as superfluous for the performance of the action, it seems that my imagined itinerary of the piece (from thing, to command, to action) was a

${ }_{23}$ Paik's interpretation was well documented, visually striking, and re-performed several times. It was soon considered a work of its own, Zen For Head, but its origin is nevertheless La Monte Young's I 960/6 I score. 
misconception. Space Transformer does not begin with the thing: the card has already been set in motion through Ono's instruction preceding it. The card (prefabricated or DIY) is thereby the performative means for the interpreter rather than the origin for his or her Space Transformer performance. Emancipating the audience is thus also to encourage it to take the matter into common hands, to paraphrase curator Maria Lind's description of collaborative artistic practice. ${ }^{24}$ Space Transformer makes us co-producers, both through the possibility to create the card ourselves, and through our performance of the instruction "Attach a card saying SPACE TRANSFORMER to the room and/or object you wish to transform." But the instruction does not hint at the outcome of our action. Instead it hooks into someone's general wish to transform and change an everyday situation, thus forcing us to reflect on our desires and everyday life. What do I want to transform? Is it transformable? Do I possess the power to transform it?

The imagined itinerary consequently takes another and unexpected route. When discussing performativity in visual arts, we often acknowledge it as an agency of a material thing (a painting, a sculpture, a stage design, or indeed the body of the artist), acknowledging its power to set off a series of effects through its specific materiality. In a large part of Fluxus's creative corpus, the material artwork was, if not subordinate to so at least equally important as its circulation. George Maciunas, often named "founder" of Fluxus, made distribution and circulation into its own artistic medium. Art historian David Joselit states: "[The] experiential transformation sought by Fluxus must necessarily be tailored to each individual person," meaning that the wish to reach out to many through a system of mass-distribution would need a careful adaptation of the piece in order to create a sense

${ }^{24}$ Maria Lind, Johanna Billing, and Lars Nilsson, Taking the Matter into Common Hands (London: Black Dog Publishing, 2007). Although the articles in the publication primarily concern contemporary artistic practice, they also trace its predecessors: collaborative artistic work, mainly from the I96os and '7os that served the goal of expanding the notion of the common. 
of urgency for the recipient. ${ }^{25}$ Maciunas built a transnational network of artists and in the process he created endless lists of addresses and contacts, distributed charts, magazines, and artworks to order via mail. He created a dense, global, and analogue system for distribution of physical material. Yoko Ono, likewise interested to reach out beyond the limited space of the art world, has from the r990s taken internet and eventually social media as prime tool for circulating her work. She has thereby enabled an almost infinite engagement in in her participatory work. Space Transformer no longer needs her in order to be materializedonce published online, the now-immaterial instruction receives a life of its own, endlessly circulating and endlessly shareable.

As the analysis of Space Transformer has shown this far, the piece bears all the traces of a Fluxus work. It is inexpensive, reproducible, easy to distribute, and it encourages the receiver to enact an instruction. Through its materiality and ability to circulate ad infinitum, the Fluxus piece navigates away from the conventional art world rounding marks, such as uniqueness, authorship, and authenticity. However, whereas Fluxus instructions are generally acting in a one-on-one situation, offering a subjective and internal interaction with the piece, Ono's online mediation suggests a wish for global transformation. The performativity of Space Transformer is thereby of a different sort than most Fluxus works, which also illustrates the more public direction that Ono's artistic work took during the late I960s, and which has continued since then. Together with John Lennon, she started using media and mass communication as an artistic tool and method to reach a wider audience than the more limited avant-garde circles had allowed. ${ }^{26}$ Most explicitly this comes forth in the War Is Over (if you want it) campaign that she has kept running through a variety of media since first launching it together with Lennon in I969:

The WAR IS OVER! campaign was once a tiny seed, which spread and covered the Earth.

${ }_{25}$ David Joselit, "The Readymade Metabolized: Fluxus in Life," RES: Anthropology and Aesthetics 63/64 (Spring/Autumn 20I3): I.

26 Concannon, "Yoko Ono’s Dreams," I05-106. 
John and I believed it helped many people to stop their wars. Since then, every WAR IS OVER! campaign has impacted the world as powerfully as the first one.

Start yours tomorrow, and you will see that it spreads and covers the world very fast and, meanwhile, makes you a Small Pebble Person.

Small Pebble People are people who know that small pebbles, when they're dropped in the ocean, will immediately affect the ocean of the whole wide world.

Don't throw a big stone. It scares people and creates repercussions.

Just drop a small pebble.

We'll keep doing it. Together.

That's how the world gets changed [...] by Small Pebble People.

We change, and the world changes. ${ }^{27}$

Throughout the duration of this project, Ono has continually developed others that in similar ways are "dependent upon a collective realization." ${ }^{28}$ Acting on the same line, Space Transformer would empower the Small Pebble Person to transform space by sticking a card to an object or space. And with this notion, we move from thing and command into the third stop of the imagined itinerary: action, very possibly the most complex of the three due to its extreme openness. Because given the status of the thingas-actant and the command that turned out to precede rather than stem from the Space Transformer card, we cannot really pin down the performative effect of the performance. Indeed, we cannot even nail who performs what in this piece. Is it the card that transforms space or your wish to do so? Is the performative agency inherent in the material thing or in your performance of the instruction? Or is it an iterative performance, produced by the agency of thing and human together? In her attempt to build a theory of vital materialism that empowers both human and non-human actants, Jane Bennett argues for a material theory in which the demystification of the object does not necessarily means privileging one

${ }_{27}$ For quote and further exploration of the project, see Yoko Ono's website Imagine Peace, accessed October 7, 2016, http://imaginepeace. com/warisover/.

${ }_{28}$ Concannon, “Yoko Ono’s Dreams,” Io6. 
before the other. A major problem in the critical theory that aims at demystifying objects, she finds, is its human-centeredness:

What demystification uncovers is always something human, for example, the hidden quest for domination on the part of some humans over others, a human desire to deflect responsibility for harms done, or an unjust distribution of (human) power. Demystification tends to screen from view the vitality of matter and to reduce political agency to human agency. ${ }^{29}$

In Ono's work, it seems that performative agency is placed in equal shares on thing, command, and action. As has become apparent when investigating the nodes that connect the three, there is no given itinerary between them. Agency can move in literally any direction. The War Is Over! campaign has spread its focus globally since its inauguration, working with mass media and social media, advertisements, and free downloads of posters from Yoko Ono's website, which-typically-is called Imagine Peace. ${ }^{3 \circ}$ Space Transformer, however, returns to the single, subjective Small Pebble Person: transform what you wish by performing this act.

In the early 2000s, curator Hans Ulrich Obrist performed a series of interviews with Yoko Ono, eventually collected and published in 2009. From some of the sections in the book, it seems however that the conversation almost took the form of performed poetry:

Hans Ulrich Obrist - What is your favorite sound?

Yoko Ono - All sounds are beautiful.

Hans Ulrich Obrist - What is your least favorite sound?

Yoko Ono - All sounds are beautiful.

Hans Ulrich Obrist - The moment we are waiting for?

Yoko Ono - We are not waiting for any moment, we are just living this moment as fully as we can..$^{3}$

Whereas the artist at times seemed spurred to provide long narratives on her work and the contexts in which she has been active,

\footnotetext{
29 Bennett, Vibrant Matter, xv (italics in original).

30 Ono, Imagine Peace, accessed October 7, 2016, www.imaginepeace.com.

${ }^{31}$ Hans Ulrich Obrist, Yoko Ono (Köln: Verlag der Buchhandlung Walther König, 2009), 66.
} 
other questions appear to have generated responses that can be characterized as a choreographed verbal interaction with the interviewer. As shown in the quote above, Ono takes command of the situation by not conforming to a conventional conversation format. She alters the relationship between interviewer and interviewee, destabilizing the power balance in the situation by undercutting Obrist's role as catalyst in command and herself as the responding object of investigation. Thus, Ono takes on the interview format, but simultaneously creates a performative effect by using a strategy that is familiar from her instruction pieces, in which she-then as catalyst in command-hands over the performance proper to someone else.

Consistent with this strategy, Ono communicates her ideas regarding art's relation to life and the individual's ability to create real change through the power of thought and imagination. Indeed, she situates the capacity to transform space as a common denominator of many of her works-or, perhaps, as a generative, performative effect of them. In relation to Grapefruit (I964/I970), her seminal collection of scores, instructions, and texts, she declares: "Grapefruit is a book of instructions and by doing those instructions you become a space transformer, each one of you." ${ }^{2}$ The instructions in Grapefruit date from the mid I950s through I964, although later editions of the publication include works that are more recent. ${ }^{33}$ Suggesting that the performance of the instructions make you a space transformer points to the idea that they all have (in one way or other) a consistent approach. They point to the individual performer, instructing (or perhaps encouraging) him or her to do something. Moreover, they often want you to do something with an object or a thing:

Lighting piece (1956)

Light a match and watch till it goes out.

Painting to be constructed in your head (1962)

Observe three paintings carefully. Mix them well in your head.

${ }^{32}$ Obrist, Yoko Ono, 67.

33 The second edition of Grapefruit was published in 1970 and has been followed by re-prints and new editions in I97I and 2000. 
The instructions in Grapefruit, thus, encourage you to take action, if only in your mind. They rarely ask you to physically destroy or reshape something, but rather to perform the change "in your head"-either explicitly or due to the fact that performing the action in real life would be physically or technically impossible. As consequence, space transforming can be apprehended as a state of mind rather than as a condition that stems from bodily action. But although declaring that you become a space transformer by following the instructions in Grapefruit, she also states that the same effect can be obtained through interaction with a single work, such as the White Chess Set (1966). The White Chess Set is a monochrome, constructed from a white chess board and only white pieces. You continue playing for "as long as you can remember where all your pieces are." ${ }^{34}$ In her talks with Obrist she elaborates:

I really think that we are more than Io०\% space transformers and through being the space transformer, and all of us can be if we believe in it. [...] As space transformers we are going to enter into the most incredible future that we will make together. I believe too, no, I know that we are all here at the beginning of the new age where we are all here to become space transformers. ${ }^{35}$

The space transformer, she seems to claim, is in fact each one of us. And if we want to, each one of us thereby have the power to change the name of the game, and the conditions under which we play it. War is over (if we want it) and if enough people want the same thing, a major transformation is about to happen. ${ }^{36}$

\section{Intermedia in Artistic Practice}

From the discussion above, we can conclude that instructions, as for example Space Transformer, are artworks in the imperative

34 Tim Stott, Play and Participation in Contemporary Arts Practices (London and New York: Routledge, 201 5), 28.

35 Obrist, Yoko Ono, 69.

${ }^{36}$ Kevin Concannon has explored this aspect of Ono's creative work, reminding of the continuous presence of faith in wishful thinking in her work. Concannon, "Yoko Ono’s Dreams." 
mood. They propose potential performance but also inhabit a performative potential, an important distinction that is also stressed by Mieke Bal when she concludes that: "Performancethe unique execution of a work-is of a different order from performativity, an aspect of a word that does what it says." 37 Indeed, a central aspect of this distinction is the fact that the inherent performativity of an instruction piece does not necessarily regard its execution or performance. Rather, the work opens up for conceptual awareness and thereby a new space for action: the mind of the receiver. This mind expands in the meeting with the instruction, through the instruction's ability to suggest contradictions, word play, improbabilities, and fantasy, all directed to the individual, subjective reader-receiver. The instruction stresses the one-on-one mode of communication by asking you to perform an action-and in doing so, it simultaneously opens up your individual interpretation of its performative claim. Does the instruction go so far as to abandon the relevance of its own materiality? It has been suggested that the format with instructions and event scores proposes

[that] the event itself is an articulation between artist and reader, paper and eyes, sound and hearing - it is a kind of secret passed in the operations of artistic practice as it attempts to extend past the object to meet the potential viewer or visitor. It is a verbalization of a possibility that suggests an entire philosophical and ontological shift that necessarily leaves the art object behind. ${ }^{38}$

As a generative effect of its performativity-occupying the receiver's mind as its main platform-the instruction piece moves in a mental sphere, which Dick Higgins would refer to as the "pre-cognitive" level of our perception. This, according to Higgins, is a level of consciousness that deals less with apprehending the basic meaning of statements, but rather relates to language as game-playing through suggesting multiple meanings and

37 Mieke Bal, Travelling Concepts in the Humanities: A Rough Guide (Toronto: University of Toronto Press, 2002), I75.

${ }^{8}$ Brandon LaBelle, "Reading Between the Lines: Word as Conceptual Project," Performance Research 7:3 (2002): 49-50. 
sentiments in the interplay of statement and receiving mind. ${ }^{39}$ The pre-cognitive apprehension of art disregards artistic medium or expression, stressing instead the effect art has on the viewer or interpreter. Once again, thus, Higgins creates a theoretical approach to art that shifts focus from the seen to the imagined and from the tangible media to the spaces where expressions merge and reshape. When Dick Higgins discussed the concept intermedia, he generally did so from his position as artist and through his experience from different artistic practices: scores, instructions, mail art, performance, visual poetry, and painting. Intermedia, Higgins argued, had been developed by artists from the I950s onwards, when moving away from traditional forms of media:

[The] media have broken down in their traditional forms, and have become merely puristic points of reference. The idea has arisen, as if by spontaneous combustion throughout the entire world, that these points are arbitrary and only useful as critical tools, in saying that such-and-such a work is basically musical, but also poetry. This is the intermedial approach, to emphasize the dialectic between the media. ${ }^{4}$

Thus, intermediality does not appear within each category according to Higgins, but is rather an effect of the fusion of different media in one and the same work, as visualized in his chart: visual art merges with poetry in poesa visiva, or is a fusion of performance and music in action music. ${ }^{4 \mathrm{I}}$ Importantly, this merge does not act at the expense of either medium, but rather boosts the combination to a new expression transgressing its different

39 LaBelle, "Reading Between the Lines," 49.

$4^{\circ}$ Dick Higgins, "Statement on Intermedia," originally in Dé-coll/age: Happenings, Stücke, Partituren, ed. Wolf Vostell (Frankfurt: Typos Verlag, I966), here quoted from Kristin Stiles and Peter Selz, Theories and Documents of Contemporary Art: A Sourcebook of Artists' Writings (Berkeley: University of California Press, I996), 729.

${ }^{4}$ F For a thorough discussion on Higgins's definition of intermedia as "fusion" and Fluxus's links to postmodern aesthetic theory, see Natilee Harren, "The Crux of Fluxus: Intermedia, Rear-guard," Art Expanded, I9581978 (Minneapolis: Walker Art Center, Living Collections Catalogue vol. 2, 20I5), accessed I6 September, 20I6, http://www.walkerart.org/ collections/publications/art-expanded/crux-of-fluxus/. 
parts. As an effect of this, the movement and space in-between become fields for intense action. This space of creative exchange and material transformation is thus where the concept's conceptions appear the most clearly.

Instruction-based art, such as the instruction paintings by Yoko Ono, are however surprisingly seldom discussed in terms of intermedia, despite their undisputable transgression of both conventional media and artistic practices. Building on the structure of the musical score, with its openness towards future performance by someone else but the author, and its acknowledgement of the freedom of interpretation, instructions constituted a core element in Fluxus. The artists used them as base for transnational mail art projects and experimental performances. Like the musical score, instructions are of course not limited to being performed in a particular context. Indeed, if returning to Higgins's intermedia concept, the artistic expressions he refers to in his chart might even be the most innovative when fueled by the space in between-for example, when an instruction is envisioned to be moving between the materiality of the written component and the interpretation and performance of it. Could it in fact be so that motion is a vital element in Higgins's understanding of intermedia? The organization of his 1995 chart (Figure 2) suggests as much. It shows a firm limit for intermedia, but just as importantly it also identifies several overlaps of the I 5 named artistic expressions, and moreover lines out empty spaces between them-indeed, there are even overlaps of the empty circles with question marks, bubbles that "may be named by the reader." ${ }^{42}$ It is easy to imagine the three-dimensionality of his chart and a constant motion and change in it. Visually, it is similar to a cluster of soap bubbles that could move and merge, expand and contract. I argue that Dick Higgins's chart, thus, illuminates movement rather than marks different ontological entities, which is something that both corresponds to his own artistic practice and to his theoretical aims at large, that is, the overall wish to take another route in the (at the time) linear visualization of art history. ${ }^{43}$ Higgins's writings

${ }^{42}$ Higgins, Modernism since Postmodernism, 2.

43 Harren, "The Crux of Fluxus," I. 
suggest a position that is standing athwart modernist art history in both content, interest, and theoretical approach. This includes his Fluxist view on authorship (or rather, his Fluxist disinterest in the same) as expressed in a letter to George Maciunas:

When the name of the artist determines the market value of a work and not its meaning in our lives-beware! And there again we come to Fluxus. In the early sixties, when the first generation of Fluxus artists were doing and giving away their experiences, it mattered little which of us had done which piece. The spirit was: you've seen it, now-very well, it's yours. Now you are free to make your own version of it if you like, and the piece and the world will be a little richer for all that. ${ }^{44}$

For Higgins, thus, the strategy to hand over the artwork to someone else was a logical effect of art's immaterial value. In addition, the gesture of handing over, or giving away, also meant that you enabled the piece to take on new forms in the hands of others, and in doing so enrich the receiver and the world alike. In a narrative that creates an intricate web of connections between things, people, and situations, Higgins builds a theoretical system that encompasses art and life and in which borders are transgressed when people ("the reader" of his chart; "you" in the letter to Maciunas) are invited to take command of the possibilities that the art offers. Similarly, Yoko Ono's instructions through their online life have come to find an even more limitless implementation than Higgins would have been able to formulate in the decades during which he explored intermedia theory. As mentioned before, the itinerary of Space Transformer is not so much decided by the material card as by the performativity-the doing-of the performance, and thereby by the decision to make the card and instruction the object that moves from silence to action. Together they open for a complex route as the instruction leaves its site and takes on new, different forms-endless, global, and by design out of the artist's control.

${ }_{44}$ Letter from Dick Higgins to George Maciunas, November I9, I974. Jean Brown papers, Getty Research Institute. Quoted in Natilee Harren, "Fluxus and the Transitional Commodity," Art Journal, (Spring 2016): 69, accessed November 17, 20I6, DOI: https://doi.org/IO.Io80/00043249.20I6.II7I 540. 


\section{Unlimited Performance, Unlimited Performativity}

My initial aim with this article was to investigate the itinerary between thing, command, and action in instruction-based art, taking my own Space Transformer card as entry point into one of Yoko Ono's emancipation projects. Was it the card that was a potential space transformer, or was it me, who could transform space by enacting the instruction and attaching the card to the room and/or object I wished to transform? But the route of the piece took unexpected turns as the thing was not-as I had imagined-predestined to precede the command, and that the action could follow from a card or piece of paper onto which anyone had written "space transformer." Thus, Space Transformer was emancipatory to a degree that opened up for almost total freedom. Ono had turned into disembodied catalyst for the piece: originator perhaps, but likewise important as mediator, through her online arrangement to spread the instruction globally and allow any kind of interpretation of it. Despite the fact that Space Transformer in its current form is a relatively recent piece, published online in the early 2000s, she has referred to the conceptual idea with space transformation as going back to her Fluxus years, particularly her book Grapefruit and the White Chess Piece (1966).45 And indeed, the format is consistent with Fluxist ideas regarding instructions as gifts to be given away. It also links to Fluxus's active avoidance of art world structures that make the artist more important than the work and that turn the work into a commodity to own and conserve; a material investment whose power lies in cultural capital rather than artwork agency.

Thus, in relation to the artwork as gift and the openness towards the recipient's own interpretation, Ono's instruction works are clearly relating to Fluxus theory. She was a central actor in Fluxus from its first official events in the early r960s and one whose work Dick Higgins developed his theoretical writings on. But is it possible to disregard Yoko Ono as the originator of Space Transformer? When theorizing Fluxus, Higgins made a strong point in putting artwork rather than artist at stage center,

${ }^{45}$ Obrist, Yoko Ono, 67. 
as shown in his letter to George Maciunas quoted earlier. It seems, however, that Ono's strategic work with mass media and mass communication since the late I960s contradicts the irrelevance of her name in relation to her projects. In fact, are not her name and fame key to the global outreach for her work? Fluxus was a transnational network that enabled artists to collaborate and interact in innumerable constellations. Through its organization, it was like an analogue predecessor to social media: an "eternal network" to use Fluxus artist Robert Filliou's term-a web that lacked a spatial as well as temporal beginning and end. Ono, however, has found a way to merge her use of mass media as creative tool with the networking strategies of Fluxus and thereby developed a firm platform for her collaborative work with audiences around the globe. To her, internet is both the logic continuation of the network idea from Fluxus's early years, as well as in keeping with the activism she partook in together with John Lennon:

All the stuff we were discussing in the 6os in terms of the global village is actually happening now. [...] It's happening on a conceptual level and it will become very physical one day-in fact, it's becoming physical already. [...]

Many writers kept predicting a doomsday future. John (Lennon) and I kept predicting a very beautiful, open future. [...] At the time we were accused of being naive by other songwriters, artists, and underground political people. We felt we stood alone. I think it is very important to keep the dialogue going and keep our future open, not closed..$^{46}$

Internet, then, has become a platform for her work that is both material and immaterial, and has both instant effect and infinite endurance. Its multiple layers remind us of Ono's partiality for puns, word play, and double meanings in the titles of her workCut Piece, Bed Peace, or indeed Space Transformer, which could be read as both noun and merit. For her, internet as medium in combination with her position as a well-known, public person have been tools for outreach. But the emancipatory effect of her

${ }^{46}$ Ono quoted in Obrist, Yoko Ono, 19. Parentheses in original. 
works remains; the act of handing over the artwork and giving the recipients agency to act on it in any way they like. In this sense, Space Transformer maintains the political project of the I960s counterculture, a context that was key also for Dick Higgins's development of his intermedia theory. If Ono took advantage of the network as political strategy, Higgins theorized on the subversive potential in fusing media. He identified a shift in artistic practices, although we (for the past decades) have become so accustomed to the effects of that shift in contemporary art that we barely notice it any more, let alone necessarily see it as politically radical. Nonetheless, by establishing the concept of intermedia, Higgins encouraged a position next to modernism's definition of artistic media and thereby opened for a stance that was not rooted in the already known and defined. But he also saw intermedia as elusive and constantly in motion:

It allows for an ingress to a work which otherwise seems opaque and impenetrable, but once that ingress has been made it is no longer useful to harp upon the intermediality of a work. [...] What was helpful as a beginning would, if maintained, become an obsession which braked the flow into the work and its needs and potentials. ${ }^{47}$

To him, intermedia was a concept that related to reconfigurations and transgressions of the known into something new. It was a fusion of different established media that resulted in novel creative expressions, often unfamiliar to the audience and thereby difficult to immediately take in and understand. Yoko Ono's instruction paintings would thereby be an illustrative example of intermediality, merging painting with poetry in a way that steers our understanding of art's mode of communication down a different route. "It is today [1998], as it was in I965, a useful way to approach some new work; one can ask oneself, 'what that I know does this new work lie between?" Higgins explains. ${ }^{4}$ Intermedia, thus, appears before the new expression is familiar and rooted in our apprehension of what is art.

47 Higgins, "Intermedia" (200I): 53.

${ }^{48}$ Higgins, "Intermedia" (200I): 53. My brackets. 


\section{References}

Bal, Mieke. Travelling Concepts in the Humanities: A Rough Guide. Toronto: University of Toronto Press, 2002.

Bennett, Jane. Vibrant Matter: A Political Ecology of Things. Durham and London: Duke University Press, 20 Io.

Brown, Carlos Cuellar. "Intermedial Being." PAJ: A Journal of Performance and Art, vol. 36, no. I (January 2014): 88-93.

Cavell, Richard. McLuhan in Space: A Cultural Geography. Toronto: University of Toronto Press, 2002.

Close, Rebecca. "Yoko Ono Work Controversy." Art Asia Pacific (Nov/ Dec 2009). Accessed September 22, 20I6. http://artasiapacific.com/ Magazine/66/YokoOnoWorkControversy.

Concannon, Kevin. "Fluxus and Advertising in the I960s... and Now." Performance Research 7:3 (2002): 55-63. Accessed November I7, 20I6. DOI: https://doi.org/IO.IO80/I3528I65.2002.I087I 874.

Concannon, Kevin. "Yoko Ono's Dreams.” Performance Research I9:2 (20I4): I03-IO8. Accessed November I7, 20I6. DOI: https:// doi.org/IO.IO8 o/I3528I65.20I4.928525.

Green, Alison. "Intermedia, Exile, and Carolee Schneemann.” Across the Great Divide: Modernism's Intermedialities, from Futurism to Fluxus, edited by Chris Townsend, Alex Trott, and Rhys Davies, I37-I 57. Newcastle upon Tyne: Cambridge Scholars Publishing, 2014 .

Harren, Natilee. "Fluxus and the Transitional Commodity." Art Journal (Spring 2016): 44-69. Accessed November I7, 20I6. DOI: https://doi.org/IO.I080/00043249.20I6.II7I 540.

Harren, Natilee. “The Crux of Fluxus: Intermedia, Rear-guard.” Art Expanded, 1958-1978. Minneapolis: Walker Art Center, Living Collections Catalogue vol. 2 (20 I 5). Accessed September I6, 20 I 6. http://www.walkerart.org/collections/publications/art-expanded/ crux-of-fluxus/.

Higgins, Dick. "Fluxus: Theory and Reception," Fluxus Research, edited by Jean Sellem, vol. 2, no. 2 (I99I): 25-46.

Higgins, Dick. Horizons: The Poetics and Theory of the Intermedia. Carbondale: Southern Illinois University Press, I984. Digital copy 
published by Ubu Editions, 2007. Accessed I7 February, 201 8. http://www.ubu.com/ubu/higgins_horizons.html.

Higgins, Dick. “Intermedia.” Leonardo, vol. 34, no. I (2001): 49-54. Commented version of I 966 article. Accessed November I7, 2016. DOI: https://doi.org/IO.II62/00240940I3000525I4.

Higgins, Dick. "Intermedia." Something Else Newsletter I, no. I. New York: Something Else Press, I966.

Higgins, Dick. Modernism since Postmodernism: Essays on Intermedia. San Diego: San Diego State University Press, I997.

Higgins, Dick. “Statement on Intermedia.” Dé-coll/age: Happenings, Stücke, Partituren, edited by Wolf Vostell. Frankfurt: Typos Verlag, I 966.

Higgins, Hannah. Fluxus Experience. Berkeley and Los Angeles: University of California Press, 2002.

Higgins, Hannah. "Intermedial Perception or Fluxing Across the Sensory.” Convergence, vol. 8, no. 4 (2002): 59-76.

Joselit, David. “The Readymade Metabolized: Fluxus in Life.” RES: Anthropology and Aesthetics 63/64 (Spring/Autumn 20I3): I90-200.

LaBelle, Brandon. "Reading Between the Lines: Word as Conceptual Project.” Performance Research, 7:3 (2002): 47-53.

Laynor, Gregory. The Making of Intermedia: John Cage to Yoko Ono, I952 to I972. PhD diss., University of Washington, 2016.

Levine, Gabriel. "The Museum of Everyday Life: Objects and Affects of Glorious Obscurity." Journal of Curatorial Studies, vol. 4, no. 3 (20I 5 ): 364-390. Accessed November I7, 20I6. DOI: https://doi.org/IO.I386/ jcs.4.3.364_I.

Lind, Maria, Johanna Billing, and Lars Nilsson. Taking the Matter into Common Hands. London: Black Dog Publishing, 2007.

Obrist, Hans Ulrich. Yoko Ono. Köln: Verlag der Buchhandlung Walther König, 2009.

Ono, Yoko. Facebook page. Accessed October I8, 2016. https:// www.facebook.com/yokoonopage/posts/IOI 504 I 7555695535.

Ono, Yoko. Grapefruit: A Book of Instructions + Drawings by Yoko Ono. New York: Simon and Schuster, 2000 [1964]. 
Ono, Yoko. Imagine Peace website. Accessed October 7, 20I6. www. imaginepeace.com.

Ono, Yoko. Instruction Paintings. New York and Tokyo: Weatherhill Inc., I995.

Program for "Terry Jennings" from Chambers Street Loft Series, Yoko Ono's Loft, New York 1960. Mimeograph on paper. Accession number 2002.97, Walker Art Center. Digitized source material. Accessed March 20, 20I 5. http://www.walkerart.org/collections/ artworks/program-for-terry-jennings-from-chambers-street-loftseries-yoko-onos-loft-new-york.

"Review: Dick Higgins, Horizons: The Poetics and Theory of the Intermedia." Poetics Today, vol. 5, no. 2 (I984): 44I.

Rothfuss, Joan. Topless Cellist: The Improbable Life of Charlotte Moorman. Cambridge: MIT Press, $20 \mathrm{I} 4$.

Sage, Elwell J. "Intermedia: Forty Years On and Beyond." Afterimage, vol. 33, issue 5 (Mars/April 2006): 25-30.

Santone, Jessica. "Archiving Fluxus Performances in Mieko Shiomi's Spatial Poem." Across the Great Divide: Modernism's Intermedialities, from Futurism to Fluxus, edited by Chris Townsend, Alex Trott, and Rhys Davies, I 20-I36. Newcastle upon Tyne: Cambridge Scholars Publishing, 20I4.

Scott Brown, Timothy. "The Sixties in the City: Avant-gardes and Urban Rebels in New York, London, and West Berlin." Journal of Social History, vol. 46, no. 4 (2013): 8I 7-842. Accessed November I7, 20I6. DOI: https://doi.org/I0.I093/jsh/shto07.

Stiles, Kristin, and Peter Selz, Theories and Documents of Contemporary Art: A Sourcebook of Artists' Writings. Berkeley: University of California Press, 1996.

Stott, Tim. Play and Participation in Contemporary Arts Practices. London and New York: Routledge, 2015.

Zurbrugg, Nicholas, ed. Art, Performance, Media: 3 I Interviews. Minneapolis and London: University of Minnesota Press, 2004. 